\title{
Metodyka badań nad autorytetem - ujęcie interdyscyplinarne
}

Esej recenzyjny książek Małgorzaty Karwatowskiej pt. Autorytety w opiniach młodzieży oraz Mirosława Rewery pt. Autorytety w świadomości młodzieży licealnej. Studium porównawcze badań uczniów I Liceum Ogólnokształcącego Collegium Gostomianum w Sandomierzu i Liceum im. Stefana Żeromskiego w Chobrzanach

Problematyka autorytetu oraz empiryczna eksploracja tego zagadnienia to tematy, które systematycznie powracają w publikacjach przedstawicieli dyscyplin nauk społecznych i humanistycznych. Z jednej strony to zagadnienie niechętnie podejmowane przez badaczy, głównie z racji trudności w operacjonalizacji pojęcia oraz w empirycznym uchwyceniu zjawiska, za pośrednictwem odpowiednich narzędzi badawczych. Z drugiej zaś badacze i teoretycy zajmujący się tematem podkreślają jego wagę i znaczenie jako wyznacznika zmienności systemu wartości (Wagner, 2010), czynnika skupiającego społeczeństwo wokół określonych celów, pełniącego jednocześnie funkcje stabilizacji i integracji (Mikołejko, 1991). Autorytet i często równolegle podejmowany wraz z nim problem systemu wartości, zarówno w badaniach, jak i rozważaniach teoretycznych, ujmowane są głównie w kontekście młodego pokolenia jako społeczności, w której te zagadnienia odgrywają rolę szczególną. Autorytety i wzory osobowe ujmowane są w tym przypadku jako

1 Paulina Markiewicz, Instytut Socjologii, Uniwersytet im. Adama Mickiewicza w Poznaniu, Polska, paulina.anna.markiewicz@gmail.com. 
istotne w procesie kształtowania tożsamości i postaw, systemów wartości i wzorów partycypacji społecznej.

Wśród publikacji o charakterze teoretycznym w sposób interdyscyplinarny i niezwykle rozległy temat autorytetu podejmuje Lech Witkowski. W publikacjach Historie autorytetu wobec kultury i edukacji oraz Wyzwania autorytetu w praktyce społecznej i kulturze symbolicznej: (przechadzki krytyczne w poszukiwaniu dyskursu dla teorii) autor dokonuje bardzo szerokiej analizy definicyjnej pojęcia, prezentuje teoretyczne tendencje w ujęciu autorytetu, wskazuje pułapki i błędy w rozumieniu zagadnienia oraz konsekwencje przyjęcia poszczególnych perspektyw jego pojmowania. W perspektywie ponowoczesności kwestią zajmuje się m.in. Zygmunt Bauman, który dostrzega zmiany w funkcjonowaniu i definiowaniu zjawiska, przesądzające o jego specyfice i oddziaływaniu. Bauman wskazuje na fragmentaryczność i tymczasowość autorytetu oraz jego masowy charakter, uzyskiwany za pośrednictwem mediów (Bauman, 1996). Prócz wyżej wskazanych (selektywnie wybranych) przykładów refleksji teoretycznej warto powołać się na podejmowane działania empiryczne, które w założeniu przynoszą obraz współczesnego społeczeństwa (młodzieży), odzwierciedlają akceptowany i uznawany system wartości oraz diagnozują rolę autorytetów w kształtowaniu tożsamości pokoleń. Empiryczne studium autorytetu oparte na metodach ilościowych przeprowadziła na grupie dorosłych Polaków Anna Mikołejko (1991) czy Iwona Wagner (2010), która diagnozuje zmienność funkcjonowania autorytetu w zmieniającym się społeczeństwie. Z kolei młodemu pokoleniu badania poświęciła Hanna Świda-Ziemba (2005), która systematycznie podejmuje temat wartości, postaw i wzorów osobowych młodzieży. Młodzi to grupa, która jest szczególnie chętnie badana w kontekście systemu wartości i autorytetu. Głównie ze względu na szczególny etap kształtowania osobowości oraz prawdopodobnie dostępność tej grupy badawczej (ankieta audytoryjna w klasach szkolnych, wytwory pracy uczniowskiej). Młodzież badana jest zatem w kontekście autorytetów metodami jakościowymi (Karwatowska, 2012), ilościowymi (Rewera, 2008), w aspekcie religijności czy autorytetu Kościoła (Wysocka, 2009; Pańkow; Rak, 2014) bądź rodziny (Sowińska, 2006). Warto także podkreślić, iż badania nad autorytetem i systemem wartości młodzieży podejmują także ośrodki badawcze. W raportach Centrum Badania Opinii Społecznej odnajdziemy raporty (m.in.): Zainteresowania, wzory i autorytety młodzieży (1992), Młodzież o sobie: wartości, obyczajowość, grupy odniesienia (1996) czy wieloaspektowe badania dotyczące młodego pokolenia: np. Młodzież 2003, Młodzież 2010 czy Młodzież 2013. Diagnozy oparte na badaniach młodzieży cieszą się szczególnym zainteresowaniem mediów, które szeroko komentują wyznaczniki kolejnych pokoleń czy „generacji”. 
W badaniach nad autorytetem dominuje przede wszystkim podejście ilościowe, co uznać można jednocześnie za atut i mankament podejścia do zjawiska. Atut, gdyż przy prawidłowym podejściu metodycznym zapewnia to możliwość uogólnień wniosków i wskazania zależności zmiennych, choć pozostając na poziomie diagnozy wyłącznie deklaracji respondentów. Problemy, jakie wskazać można w metodyce badań nad autorytetem, to przede wszystkim: brak szczegółowej operacjonalizacji pojęcia w przełożeniu na język operacji badawczych i trafne narzędzia, brak triangulacji metodologicznej lub na poziomie technik badawczych, liczebność próby i sposób jej doboru (trudności w osiągnięciu reprezentatywności) oraz daleko idące uogólnienia i generalizacje. Zachowanie standardów procedur badawczych oraz zasad generalizacji wyników badań jest o tyle ważne w perspektywie omawianego zagadnienia, iż dyskusja odnośnie do autorytetów budzi wiele emocji nie tylko wśród przedstawicieli nauk społecznych, ale także mediów. Powodem podejmowanych dyskusji jest zarówno obwieszczany kryzys autorytetów, jak i diagnozowana niezmienność systemów wartości młodzieży, uznanie dla charyzmatycznych i poważanych autorytetów (np. Jana Pawła II) oraz osobowości medialnych (Kuba Wojewódzki czy Jerzy Owsiak). Pewna sprzeczność wyników badań, a z pewnością wyciąganych wniosków wydaje się charakterystyczna dla badań nad systemami wartości młodzieży i ich autorytetami (Markiewicz, 2015). W jednych raportach i opracowaniach odnajdujemy konkluzje, iż młodzież nie ma potrzeby posiadania autorytetu, charakteryzuje się wysokim poczuciem indywidualizmu, a w swoich decyzjach odwołuje się wyłącznie do własnego sumienia (Mariański, 2001; Świda-Ziemba, 2005), inne pokazują, iż „generalnie młodzież deklaruje głód autorytetów” (Wysocka, 2009). W dużej mierze różnica w uzyskiwanych wynikach badań oraz wnioskach konstruowanych na ich podstawie jest konsekwencją przyjętej (odmiennej) optyki autorytetu, która rzutuje na kwestie definicyjne (a te warunkują operacjonalizację) oraz kształt procesu badawczego. Tylko wdrożenie rzetelnego warsztatu badawczego gwarantuje trafną diagnozę zjawiska. Umożliwia uogólnianie wniosków (w przypadku metod ilościowych) lub próbę zrozumienia pojmowania autorytetu (przez grupę badawczą) czy ukazanie jego znaczenia w procesie kształtowania osobowości (w przypadku metod jakościowych). Jest to o tyle istotne, iż warunkuje interpretacje i wnioski odnoszące się (głównie) do młodego pokolenia, a diagnozy dotyczące młodzieży często stają się drogowskazem w podejmowaniu decyzji indywidualnych czy systemowych, np. w zakresie modelowania procesu pedagogiczno-dydaktycznego czy tworzeniu programów profilaktycznych. Warto zatem bliżej przyjrzeć się sposobom organizacji i wdrażania metodyki badań znaczenia i roli autorytetu wśród młodzieży na przykładzie wybranych różniących się podejść. 
W celu wskazania stosowanych praktyk w zakresie badań nad autorytetem dokonano poniżej porównawczej analizy warsztatu metodycznego reprezentowanego przez przedstawicieli dwóch odmiennych dyscyplin badawczych - lingwistyki (Małgorzata Karwatowska) i socjologii (Mirosław Rewera), którzy zaplanowali i wdrożyli empiryczny warsztat badań nad autorytetem. Publikacje mimo zbieżności poruszanych zagadnień prezentują odmienne podejście badawcze, nie tylko pod względem stosowanych metod (ilościowe vs jakościowe). Autorzy przejawiają przede wszystkim różną praktykę wobec sposobu gromadzenia danych, zgromadzonego materiału empirycznego, a przede wszystkim standardów metodycznych obowiązujących w kolejnych etapach procesu badawczego. Na podstawie omawianych publikacji w artykule starano się odzwierciedlić podejmowane przez badaczy kolejne kroki i decyzje badawcze, ze szczególnym wskazaniem ich mocnych i słabych stron.

O ważności podejmowanego zagadnienia oraz potrzebie jego empirycznej eksploracji informuje Małgorzata Karwatowska już we wstępie książki. W tej część publikacji autorka przytacza wnioski badaczy nauk społecznych, obrazujące aktualną kondycję tradycyjnie pojmowanych autorytetów i ich malejące znaczenie we współczesnym społeczeństwie (por. s. 9-12). Wstęp zapowiada także empiryczny cel prezentowanego opracowania oraz wieloaspektowe ujęcie autorytetu, podyktowane głównie jego interdyscyplinarnym charakterem. Autorka wskazuje, iż w pracy postara się odpowiedzieć na następujące pytania: 1) Jak młodzież szkół średnich rozumie autorytet? 2) Jaki jest stosunek młodych ludzi do tego pojęcia? 3) Czy licealiści potrzebują autorytetów i kogo uznają za wzory do naśladowania, za osoby znaczące, ważne, które są w stanie wpływać na ich sposób postępowania? Pytania te stawiane będą na pierwszym etapie badań, natomiast celem drugiego etapu jest „kognitywistyczne przedstawienie językowych obrazów matki, ojca i nauczyciela (...), a podstawą analizy, interpretacji i wnioskowania staną się autentyczne werbalizacje tworzone przez młodzież”. Warto w tym miejscu jeszcze raz podkreślić, iż choć badaczka jest lingwistką w pracy, niejednokrotnie powołuje się i jednocześnie stara wdrożyć metodyczny warsztat nauk społecznych.

Natomiast wstęp do książki Mirosława Rewery sygnalizuje, iż jest to praca koncepcyjnie bardziej zaawansowana pod względem metodycznym. Prócz uzasadnienia podejmowanego tematu, odwołań empirycznych i teoretycznych wskazujących na istotę problemu autor zamieszcza w tym miejscu publikacji listę pytań badawczych, na które poszukiwał będzie odpowiedzi w trakcie realizacji badań, a które jednoczenie analizować będzie ze względu na wybrane zmienne (np. płeć, pochodzenie społeczne uczniów, a także uczestnictwo we Mszy Świętej) (por. s. 13). We wstępie poza nakreślonym obszarem badawczym odnajdujemy 
także wyartykułowane przez badacza hipotezy: zarówno ogólną, jak i trzynaście hipotez szczegółowych.

Rozdział pierwszy książki Małgorzaty Karwatowskiej, noszący tytuł Sq̨dy badaczy o autorytecie, zawiera szereg odwołań definicyjnych pojęcia autorytetu, które jako podstawowe wyznacza granice podjętych badań empirycznych. Te szczególnie zauważalne to głównie odwołania słownikowe i encyklopedyczne. W tekście odnajdujemy definicje słownikowe pochodzące z Praktycznego słownika współczesnej polszczyzny (1994), Słownika współczesnego języka polskiego (1996), Uniwersalnego słownika języka polskiego (2003), Innego słownika języka polskiego (2000), Małego słownika etycznego (1999), Leksykonu filozofii klasycznej (1997), Encyklopedii psychologii (1998), Encyklopedii pedagogicznej (1993) i Katechizmu Kościoła katolickiego (1994). Zestawienie pojęć, ograniczające się niemal wyłącznie do cytowań, zamyka wyróżnienie listy typów i rodzajów autorytetów, dokonywane przez innych autorów i badaczy. Przytaczane typologie konstruowane są w oparciu o kryterium funkcjonalne, uznania lub podmiotowe. Szczególne miejsce zajmuje rozróżnienie zaproponowane przez Ericha Fromma „mieć autorytet” i „być autorytetem”, któremu autorka poświęca akapit, przywołując spostrzeżenia i rozważania innych autorów traktujących zagadnienie autorytetu w tym kontekście. Przyznać należy, iż zestawienie zawiera wiele odwołań i odsyła czytelnika do obszernego katalogu literatury, jednak nadal to wręcz fundamentalne dla całej rozprawy i podejmowanych przez autorkę decyzji badawczych pojęcie pozostaje przedstawione w sposób słownikowy jako spis bądź wykaz definicji.

W odmienny sposób kwestię definicyjną autorytetu podejmuje Mirosław Rewera. W pierwszym rozdziale publikacji uwzględnia pojawiające się w literaturze przedmiotu kontrowersje wokół pojęcia, odwołuje się do klasycznych teorii socjologicznych i także w nich poszukuje rodzajów autorytetu. Analogicznie jak Małgorzata Karwatowska autor podejmuje się wyodrębnienia typów autorytetu, przytacza jego klasyfikacje, a także przywołuje wybrane funkcje autorytetu. Wskazując na zainteresowanie autorytetem już w czasach Starożytności, autor nie skupia się na ujęciu słownikowym pojęcia, lecz odnosząc zagadnienie do pozycji literaturowych głównie z obszaru socjologii i pedagogiki (także prac o charakterze empirycznym), pokazuje wielość możliwości poszukiwania i wyznaczania desygnatu pojęcia autorytetu. Zainspirowany przeglądem socjologicznych teorii autorytetu Mirosław Rewera na kolejnych stronach publikacji analizuje zagadnienie z punktu widzenia perspektyw teoretycznych zaproponowanych przez Annę Mikołejko, uzupełniając katalog paradygmatów o dodatkowe ujęcia. Wtórnie (za: Mikołejko) autor przywołuje pozytywistyczną optykę Emila Durkheima, ujmującego autorytet w kategoriach przymusu na jednostkę, nie do 
końca spójne rozważania George’a Simmla oraz refleksję Webera, dla którego autorytet wpisuje się w szerszy kontekst analizowanego zjawiska panowania. Zestawienie ujęć zaczerpniętych od Anny Mikołejko zamyka pogłębiona analiza perspektyw Talcotta Parsonsa i Roberta Mertona. Dodatkowo w ramach uzupełniania odniesień teoretycznych Mirosława Rewera powołuje się na publikacje Znanieckiego, na podstawie których stara się zrekonstruować quasi-koncepcję autorytetu, kompatybilne w tym zakresie teorie Petera Blaua i Georga'a Homansa oraz ponowoczesne ujęcie Zygmunta Baumana. Rozdział ten, w którym autor dokonuje klasyfikacji autorytetu w oparciu o przyjęte (różnorodne) kryteria, wymienia wielość funkcji, jakie pełni autorytet, zamyka część, w której przywołuje swoistą kronikę badań nad autorytetem prowadzonych wśród młodzieży polskiej. Historia empirycznej eksploracji zagadnienia prezentowana przez Mirosława Rewerę sięga dwudziestolecia międzywojennego. Autor poprzez kolejne dekady XX wieku (prócz lat 1944-1956, kiedy to odnotowuje lukę w wynikach badań), przywołuje liczne pozycje empiryczne i raporty, które w sposób mniej lub bardziej bezpośredni dotykały problemu postrzegania autorytetu przez młode pokolenia. Katalog prezentowanych wyników zamykają badania Jana Zimnego, datowane na rok 2005. Warto podkreślić, iż liczne przywołania są szczególnie cennym przeglądem dokonań empirycznych, które służyć mogą badaczom poszukujących odniesień do zagadnienia autorytetu.

Wyodrębniony rozdział metodyczny odnajdujemy tylko w publikacji Mirosława Rewery. W tej części opracowania autor stara się opisać warsztat, który wdrożył w trakcie realizacji procesu badawczego. Najobszerniejszy fragment rozdziału to jednak ogólna charakterystyka miejscowości i szkół, w których realizowano badania. Zarówno Sandomierzowi, jak i Chobrzanom autor poświęcił znaczną część rozdziału drugiego, opisując położenie, wielkość terytorium, etymologię nazwy miejscowości oraz historię, rozwój gospodarki i szkolnictwa, począwszy od pierwszej wzmianki w Kronice Galla Anonima (w przypadku Sandomierza). Kolejne podrozdziały obejmują już opis metodyczny stosowanego warsztatu. Po wstępie dotyczącym sposobów doboru „próbki reprezentacyjnej” w naukach społecznych odnajdujemy wzmiankę, iż dobór w opisywanych badaniach miał charakter celowy ze względu na położenie miejscowości (czyli miejsce zamieszkiwania młodzieży), gdzie w tym przypadku Chobrzany, jak wskazuje autor, to miejscowość „typowo wiejska”, a „w liceum w Sandomierzu uczy się w zdecydowanej większości młodzież zamieszkująca środowisko miejskie”. Badania, jak wskazuje Mirosław Rewera, miały charakter dwuetapowy (realizowane za pomocą tego samego kwestionariusza w latach 2002 i 2004), w celu wskazania dynamiki opinii uczniów na temat autorytetów, gdzie zakładanym czynnikiem 
zmiany miało być wstąpienie Polski do Unii Europejskiej, które nastąpiło w maju 2004 roku. W pierwszym etapie badań próba wyniosła 158 uczniów (po 79 licealistów z Sandomierza i Chobrzan), a w drugim (2004 roku) 177 licealistów (75 z Chobrzan i 84 z Sandomierza). Wskazanie liczebność poszczególnych prób jest o tyle ważne, ponieważ w dalszej analizie wyników może mieć ono istotne znaczenie dla wyciąganych wniosków i stosowanych uogólnień. Autor stara się także uzasadnić w rozdziale wybór młodzieży licealnej jako zbiorowości badanej. Powołując się na publikacje z lat 60. i 70. Hanny Świdy, Reginy Łapińskiej i Marii Żebrowskiej, wskazuje na okres wczesnej adolescencji jako ten, w którym kształtuje się już osobisty stosunek do zjawisk społeczno-kulturowych, wzmożone zaangażowanie oraz intensywny proces krystalizowania się tożsamości (por. s. 70). W dość niezrozumiały sposób autor uzasadnia także celowość wyboru młodzieży uczącej się w liceach ogólnokształcących. Badacz argumentuje, iż młodzież ta, z większym prawdopodobieństwem (w stosunku do uczniów liceów zawodowych, techników czy szkół zawodowych), kontynuować będzie naukę na studiach wyższych i „,w dalszej perspektywie wejdzie w skład inteligencji, czyli warstwy społecznej, która z założenia przynajmniej jest odpowiedzialna za rozwój i postęp społeczny”. Dodatkowo autor, nie przeprowadzając żadnej analizy teoretycznej i nie przytaczając danych empirycznych, zakłada, iż młodzież ta wykazuje większą wrażliwość na sprawy społeczno-kulturalne (także w stosunku do autorytetów) niż uczniowie innych typów szkół (por. s. 70). Rozdział zamyka ogólny opis stosowanego kwestionariusza ankiety, noszącego tytuł „Autorytety w świadomości młodzieży”, przebiegu badań oraz charakterystyka zbiorowości badanej, na podstawie danych metryczkowych wg zmiennych: miejsce zamieszkania, pochodzenie społeczne uczniów (w tym szlacheckie), częstotliwość uczestnictwa we Mszy Świętej oraz stosunek do wiary.

Tak skonstruowanego rozdziału metodycznego nie odnajdziemy w publikacji Małgorzaty Karwatowskiej. Uzasadnienie decyzji metodycznych czy opis wdrożonego warsztatu empirycznego to zaledwie kilka ogólnych zdań, które przeczytamy bądź we wstępie, bądź w przypisach do poszczególnych fragmentów pokazujących wyniki badań. W rozdziale drugim, w którym autorka rozpoczyna prezentację zgromadzonych danych, zamieszczono notkę (w przypisie), iż analiza jakościowa prowadzona w opracowaniu wzbogacona jest ilościową, która zdaniem badaczki poprzez stosowanie metod statystyki matematycznej wzbogaca analizę i jest użyteczna zarówno w interpretacji danych ankietowych, jak i materiału tekstowego (por. s. 40). W praktyce jednak zapowiadany sposób analizy to zliczenie częstości wskazywanych przez uczniów odpowiedzi, np. na podstawie katalogu wartości, zaprezentowanego badanym, a następnie zastosowaniu instrukcji co wyboru 
hierarchii najważniejszych. Dalszy sposób prowadzonej analizy to przytaczane cytaty odpowiedzi udzielonych w ankiecie, które obrazują i uzasadniają wybory dokonywane przez badanych. Małgorzata Karwatowska przywołuje poszczególne wypowiedzi uczniów, odnosząc je do wyników badań prowadzonych przez innych badaczy, m.in. Janusza Czapińskiego, Janusza Mariańskiego, Jacka Sierdzana czy Hanny Świdy-Ziemby (por. s. 41-52). Warto zwrócić uwagę, iż w odwołaniach i interpretacjach wyników badań dotyczących kwestii prawdy czy sumienia autorka przywołuje także encykliki Jana Pawła II. W odniesieniu do pierwszego rozdziału empirycznego warto odnotować dwie kwestie. Po pierwsze, opis danych zebranych na podstawie badań własnych poprzedza szeroka analiza i uzasadnienie łączenia badań nad autorytetem i systemem wartości, poparta implikacjami teoretycznymi innych autorów. Dodatkowy element stanowi przegląd empirycznych projektów prowadzonych od lat 70. w zakresie preferencji aksjologicznych młodzieży polskiej. Po drugie, w zakresie doboru próby autorka nadmienia wyłącznie o roku realizacji badań, liczbie respondentów oraz zmiennej ich charakteryzującej: „licealiści szkół lubelskich”. Brak opisu doboru próby i uzasadnienia decyzji badawczych nie byłby o tyle rażący, gdyby w dalszym postępowaniu badawczym autorka rzeczywiście ograniczyła się wyłącznie do analizy jakościowej.

Oczywiste dla badacza może być stwierdzenie, iż określenie liczebności populacji generalnej, próby oraz sposobu jej pobrania ma niezwykle istotne znaczenie dla rzetelności i wiarygodności badań. Dobór próby faktycznie warunkuje możliwość wnioskowania statystycznego i możliwość przeprowadzenia uogólnień, a osiągnięcie reprezentatywności jest niezwykle trudne i uzależnione od spełnienia określonych założeń. Idealną sytuacją jest oczywiście sposobność realizacji doboru losowego, jednak chociażby ze względu na wymóg uwzględnienia operatu losowania to dla badacza sytuacja bardzo rzadka - tylko taka umożliwia uogólnienie uzyskanych wyniki badań z określonym przybliżeniem i określonym ryzykiem błędu na populację, z której próbę wylosowano (Nowak, 2006). W omawianych publikacjach znajdujemy jednak informację o celowym dobrze próby. Mirosław Rewera wybrał w ten sposób dwie miejscowości, kierując się intencją wskazania różnic środowiskowych w obszarze miejskim i wiejskim. Sam wybór miejscowości, szkół czy klas, które zostały włączone do badań, nie został opisany. Prawdopodobnie odbył się na zasadzie „dostępności”. Można zatem przypuszczać, iż na żadnym etapie doboru próby nie wprowadzono elementu probabilistycznego. Z jednej strony tłumaczy to powierzchowność prowadzonych analiz, gdyż większość operacji statystycznych i metod testowania wymaga założenia losowego doboru próby (Blalock, 1997), z drugiej jednak stanowi daleko idące ograniczenie badań, szczególnie tych mających wykazać zmiany podstaw i opinii. Dodatkowo próby 
porównań młodzieży wiejskiej i miejskiej, na podstawie wyboru Sandomierza liczącego niespełna 25 tys. mieszkańców i Chobrzan, mogą wzbudzać uzasadnione zastrzeżenia - wskazano na celowość doboru określonych zmiennych (społeczność miejska vs wiejska), jednak sposób doboru miejscowości, szkół czy klas mógł pozostać losowy np. w danym województwie. Z kolei w przypadku badań Małgorzaty Karwatowskiej o faktycznej liczebności populacji generalnej czy sposobie doboru próby odbiorca nie wie niemal nic. We wstępie autorka wskazała, iż „wszystkie badania prowadzone były Lublinie, a uczestniczyło w nich łącznie ponad 1120 uczniów”. Autorka wskazuje zatem, że liczebność badanych sięga ponad tysiąc osób i jednocześnie argumentuje (powołując się na literaturę przedmiotu), iż jest to próba duża, gdyż przekracza stu badanych (por. s. 13). Oczywiście założenie próby tysiąca respondentów dotyczy metod ilościowych, przy założeniu losowego jej doboru, a sama badaczka, dokonując metodycznego nadużycia, nie wskazuje w tym miejscu, że na wspomnianą grupę tysiąca osób, składa się kilka mniejszych projektów badawczych z zastosowaniem różnych narzędzi. W rezultacie, śledząc poszczególne rozdziały pracy, czytelnik z wielkim trudem przelicza i sumuje grupy uczniów, na których realizowano badania tak, aby zrozumieć decyzje badawcze i etapy postępowania badawczego.

W kolejnych rozdziałach omawianych publikacji autorzy prezentują wyniki badań w podziale na kategorie tematyczne, odpowiadające częściom kwestionariusza (w przypadku badań Mirosława Rewery) lub w zastosowaniu poszczególnych narzędzi badawczych (Małgorzata Karwatowska). Te części pracy autorzy rozpoczynają od wskazań i wypowiedzi badanych dotyczących pojmowania autorytetu. Zestandaryzowane narzędzie zaproponowane przez Mirosława Rewerę obligowało respondenta do wskazania możliwych zaproponowanych w kafeterii sposobów rozumienia autorytetu oraz wyboru kategorii uznawanej za najważniejszą. Pozostałe kwestie dotyczące potrzeby posiadania autorytetów, ich cech konstytutywnych czy osób lub podmiotów pełniących funkcje autorytetów zawarto w kolejnych pytaniach narzędzia. W przypadku badań Małgorzaty Karwatowskiej uczeń mógł podać wyrażenia i zwroty kojarzące się ze słowem autorytet, zbudować własną definicję rzeczownika (w dalszej części wskazać cechy charakteryzujące autorytet) oraz wymienić osoby, które uznawane są przez uczniów za takowy. Warto nadmienić, iż w tym przypadku „ankieta” skonstruowana była z ośmiu otwartych pytań, pozwalających młodzieży na swobodną wypowiedź.

Chociażby ze względu na odmienność prezentowanych przez badaczy dyscyplin wyróżnić możemy dwa rodzaje podejścia do zgromadzonych danych i sposobie ich analizy. Mirosław Rewera prezentuje głównie podejście ilościowe, jednak zaznaczyć należy, iż w odniesieniu do możliwości statystycznych w bardzo 
ograniczonym zakresie. Podstawą przedstawienia danych są tabele krzyżowe i zestawienia ze względu na datę przeprowadzenia badań (dwa etapy realizacji) i miejscowość pomiaru. Tabele prócz ogólnej liczby badanej podzbiorowości wskazują tylko na dane procentowe dla poszczególnych kategorii odpowiedzi, co w przypadku małych liczebności dla poszczególnych zmiennych $(\mathrm{N}=14, \mathrm{~N}=7$, $\mathrm{N}=3$ ) nie odzwierciedla w sposób właściwy rozkładu analizowanej cechy. Dodatkowo warto odnotować, iż analiza statystyczna materiału kończy się faktycznie na prezentacji tabel. Obliczenia to wyłącznie procentowanie odpowiedzi ze względu na wybraną zmienną.

Analiza materiału przeprowadzona przez Małgorzatę Karwatowską ma charakter głownie jakościowy z uzupełnieniem ilościowym, które jest prostym zliczeniem wskazywanych odpowiedzi i nie opiera się na działaniach statystycznych. Należy podkreślić, iż zestawienia wypowiedzi respondentów prócz listy najczęściej wskazywanych kategorii ujmowane są przez autorkę także w typologie, adaptowane wtórnie na podstawie badań i literatury innych autorów oraz tworzone samodzielnie na gruncie analizy zgromadzonego materiału. Analizie jakościowej autorka poddała przede wszystkim materiał zgromadzony na podstawie ankiet opartych wyłącznie na pytaniach otwartych oraz wypowiedziach pisemnych licealistów dotyczących bohaterów literackich. Na tej podstawie badaczka tworzy klasyfikacje definicji autorytetu, które wyodrębniła na podstawie objaśnień uczniów zawartych w odpowiedziach na pytania otwarte oraz typologię bohaterów typowanych przez uczniów, w odniesieniu do postaci realnych i fikcyjnych. O wiele ciekawszym od prezentowanej analizy jakościowej, z uzupełnieniem skromnej analizy ilościowej, wydaje się ta o charakterze leksykalno-semantycznym, np. na podstawie domen jednostki leksykalnej słowa matka czy ojciec zaproponowanych przez Georga Lakoffa (por. s. 106) czy Roberta Taylora (por. s. 128). Materiał do tego rodzaju analizy badaczka pozyskała w sposób odmienny - w tym przypadku nie wykorzystała wyłącznie narzędzi badawczych, nawet tych o małym stopniu standaryzacji, ale zebrała dane także na podstawie wypracowań uczniów liceów i szkół podstawowych oraz listów, których autorami byli uczniowie. Odpowiednio zebrano sto wypracowań oraz łącznie dwieście listów, dodatkowo zgromadzono ankiety z pytaniami otwartymi. Na początku analizy każdego zgromadzonego materiału leksykalnego autorka wyodrębnia pytania i zamierzenia badawcze, którym służyć ma dany projekt empiryczny, jednak nie zawsze punkty te artykułowane są na tyle wyraźnie, iż czytelnik ma świadomość, jaki był zakres badań, a przede wszystkim jak wyglądał proces gromadzenia danych oraz ile osób wzięło udział w badaniu na danym etapie nauczania czy za pośrednictwem danego narzędzia. Rozdział ostatni prezentujący uczniowskie wzorce osobowe zamyka obraz nauczyciela - wyniki 
badań autorka także przedstawia za pomocą wyodrębnienia poszczególnych cech (zakresów) nauczyciela, tzw. domen.

Przyjęty przez Mirosława Rewerę schemat analizy nie odbiega od przyjętych standardów w zakresie prezentacji wyników. Rozdziały od trzeciego do dziewiątego są odzwierciedleniem poszczególnych obszarów tematycznych umieszczonych w obszernym narzędziu badawczym - kwestionariuszu ankiety. Odpowiednio analizie poddane zostały: sposoby pojmowania autorytetu, problematyka wartości w odniesieniu do autorytetu, autorytet rodziców, nauczycieli i wychowawców, autorytety polityczne, religijne (w tym Kościoła katolickiego, księży oraz Jana Pawła II) oraz pozostali znaczący w świadomości młodzieży. W każdym z rozdziałów odnajdujemy odwołania empiryczne do wcześniej publikowanych wyników badań lub raportów realizowanych głównie przez CBOS bądź w odniesieniu do populacji ogólnej Polaków bądź w zakresie badań młodego pokolenia. Prezentację wyników badań własnych autor umieszcza także w kontekście wniosków i analiz prowadzonych przez teoretyków i badaczy podejmujących zbliżone zagadnienia badawcze. Mimo dość powierzchownej analizy danych ilościowych zgromadzony materiał badawczy przedstawiony został dość szczegółowo - głownie za sprawą rozbudowanego narzędzia badawczego, które umożliwiło zebranie danych odnoszących się do bardzo wąskich obszarów/podmiotów funkcjonowania autorytetów. Szereg pytań w kwestionariuszu poświęcono rodzinie, nauczycielom, instytucjom i postaciom życia publicznego, ale także szczególne miejsce w ankiecie zajmują pytania dotyczące autorytetu księży i duchownych oraz wyodrębniony blok pytań dotyczący Jana Pawła II i osobny dotyczący Kościoła katolickiego. Taka specyfikacja obszarowa narzędzia oraz konstrukcja wyłącznie pozytywnych skal odpowiedzi odnośnie do poszczególnych postaci rodzi pytania, sugestie, odpowiedzi oraz trafność narzędzia. Warto podkreślić, iż rozdziały analityczne zamyka zestawienie wybranych tabel krzyżowych prezentujących dane, które nie znalazły omówienia w głównej części publikacji.

To, co łączy autorów i dodatkowo może być szczególnie docenione przez odbiorców śledzących warsztat metodyczny wdrażany przez badaczy różnych dyscyplin naukowych, jest możliwość wglądu w zastosowane narzędzia badawcze. W przypadku pracy Mirosława Rewery to zestandaryzowany kwestionariusz ankiety, zawierający ponad siedemdziesiąt pytań wraz z kafeteriami odpowiedzi i zastosowanymi skalami. Takie swoiste „ujawnienie” narzędzi, rzadko jeszcze spotykane na gruncie socjologii, pozwala nie tylko na ocenę trafności stosowanych rozwiązań, ale daje możliwość powtórnego zastosowania w np. w badaniach porównawczych czy ewentualnej korekcji pytań, skal czy kategorii odpowiedzi. Natomiast w przypadku publikacji Małgorzaty Karwatowskiej w aneksie do pracy 
zamieszono nie tyle narzędzia badawcze, ile przykłady prac uczniowskich - wypełnione kwestionariusze, konstruowane głównie na podstawie pytań otwartych, oraz przykłady listów i wypracowań.

Podsumowując warsztat metodyczny zastosowany przez Małgorzatę Karwatowską, z całkowitą stanowczością można stwierdzić, iż jest on zróżnicowany pod względem zastosowanych technik badawczych, a raczej sposobów gromadzenia materiału. Niestety, brak rozdziału metodycznego, bardzo ogólne, a wręcz zdawkowe opisy wdrażanych metod badawczych (również sposobów analizy) oraz nikła charakterystyka próby badawczej (określenie tylko i wyłącznie jej liczebności) nie pozwalają na ocenę rzetelności i trafności zgromadzonych danych. Autorka we wstępie pracy określa ogólną liczbę badanych uczniów, jednak nie wspomina, iż z zastosowaniem kolejnych sposobów zbierania materiału (ankieta dotycząca wartości, ankieta dotycząca autorytetu, wypracowania, listy) próba ta zmienia swoją liczebność, wskazana początkowa liczba to suma pomniejszych prób. Oprócz faktu, iż badania realizowano na grupie uczniów szkół lubelskich, o badanej zbiorowości nie wiemy zupełnie nic. Prócz wskazań, jaka liczba badanych brała udział w poszczególnym mniejszym badaniu, autorka nie zamieszcza żadnych informacji o sposobie doboru respondentów, ich wieku, innych zmiennych społeczno-demograficznych. Nie uzyskujemy także informacji, czy w ramach poszczególnych pomniejszych badań udział brały te same jednostki, czy każde badanie realizowano w innej placówce edukacyjnej. Z pewnością odpowiedzi na powyższe pytania i wskazane wątpliwości powinny zostać udzielone w rozdziale prezentującym koncepcję realizowanych badań, zastosowane narzędzia badawcze oraz sposoby i logikę planowanej analizy materiału. Tak skonstruowany rozdział pozwoliłby odbiorcy, niewątpliwie ciekawego opracowania, na odnalezienie się w prezentowanym materiale badawczym oraz umożliwił jego metodyczną ocenę. Owszem, trudno jest przykładać miarę i standardy badań nauk społecznych do osiągnięć badawczych dokonywanych na obszarze innych dyscyplin naukowych, jednak nie byłoby to zasadne, gdyby autorka nie przejawiała ambicji teoretycznych, metodycznych i analitycznych z zakresu socjologii, powołując się na autorów i badaczy tej dziedziny, przytaczając ich osiągnięcia badawcze i teoretyczne, posługując się narzędziami, terminologią nauk społecznych, a w końcu dokonując analizy i wnioskując w odniesieniu do obszarów społecznych.

Praca Mirosława Rewery, prezentująca studium porównawcze, to przede wszystkim bardziej usystematyzowane przedstawienie warsztatu metodycznego, dość szczegółowy opis badanej próby i ilościowe, choć raczej powierzchowne podejście do materiału. Niedosyt dla czytelnika szukającego opisu poszczególnych etapów procesu badawczego pozostawia przede wszystkim brak uzasadnienia 
procedury i objaśnienia kryteriów celowego doboru próby oraz płytka analiza statystyczna, na podstawie której autor potwierdza stawiane w badaniach założenia. Wnikliwa analiza narzędzia badawczego, szczególnie pod względem konstrukcji pytań, ich kolejności czy zastosowanych skal, także może budzić wątpliwości wśród empiryków, jednak warto zauważyć, iż brak testowania narzędzia i niechęć do konsultacji eksperckich w tym zakresie to ogólna słabość warsztatu metodycznego socjologii. Niewątpliwie atutem pracy jest obszerna analiza koncepcji autorytetu odwołująca się do klasycznych teorii socjologicznych oraz imponująca liczba odniesień empirycznych w zakresie interpretacji wyników badań.

W badaniach nad autorytetem nadal brakuje zatem przykładu badań niebudzących wątpliwości pod względem rzetelności, trafności stosowanych narzędzi czy możliwości generalizacji na podstawie gromadzonych danych. Warto podkreślić, iż w omawianych publikacjach prezentowano wyniki badań realizowanych wyłącznie na młodzieży szkolnej, zamieszkującej wschodnie obszary kraju, co bez wątpienia ma znaczenie. Młodzież, jak zostało to już opisane, to łatwo dostępna grupa badawcza, a w kontekście badań nad autorytetem czy systemami wartości bardzo pożądana. Mimo takich możliwości badawczych fundamentalne zasady realizacji procesu badawczego są swobodnie wdrażane, a sam warsztat metodyczny nadal pozostaje słabo opisany. Biorąc pod uwagę wnioski i interpretacje, jakich dokonują badacze, daleko idące uogólnienia, jakie stosują oraz znaczenie poruszanych kwestii, wydawać by się mogło, iż standardy warsztatu metodycznego nie powinny budzić żadnych (bądź tak zasadniczych wątpliwości), zarówno w określaniu liczebności populacji generalnej, sposobie doboru próby (który faktycznie warunkuje możliwości generalizacji), jak i prowadzonych analizach i stosowanych procedurach statystycznych. Granice w stosowaniu metodyki jakościowej i ilościowej są dość wyraźnie określane i choć dopuszczalna, czy nawet preferowana, obecnie triangulacja metodologiczna daje możliwość prowadzenie badań pogłębionych, decyzje badawcze powinny mieć swoje uzasadnienie, ale i konsekwencje. Zatem stosując metody ilościowe, nie ograniczajmy się do doborów celowych jednostek łatwo dostępnych, przy dodatkowo dość niskiej liczebności próby i powierzchownych krzyżowych analizach częstości - to daje dość ogólny i wyłącznie wstępny obraz zjawiska, ograniczonego ściśle do danego terytorium. Przy zastosowaniu jakościowych metod badań, poza standardami kwalifikacji jednostek do próby, warto również prezentować cały warsztat badawczy (od opisu populacji do sposobów analizy, w tym sposobów kodowania materiału jakościowego na zmienne ilościowe) - tak, aby odbiorca mógł ocenić rzetelność prowadzonych badań i wartość zgromadzonych danych. 


\section{Literatura:}

Babbie, E. (2005). Badania społeczne w praktyce. Warszawa: PWN.

Bauman, Z. (1996). Socjologia. Warszawa: Zysk i S-ka.

Blalock, H.M. (1977). Statystyka dla socjologów. Warszawa: PWN.

Karwatowska, M. (2012). Autorytety w opiniach młodzieży. Lublin: Wydawnictwo Uniwersytetu Marii Curie-Skłodowskiej.

Mayntz, R., Holm, K., Hubner, P. (1985). Wprowadzenie do metod socjologii empirycznej. Warszawa: PWN.

Mikołejko, A. (1991). Poza autorytetem? Społeczeństwo polskie w sytuacji anomii. Warszawa: KeyTex.

Nowak, S. (2007). Metodologia badań społecznych. Warszawa: PWN.

Rewera, M. (2008). Autorytety w świadomości młodzieży licealnej: Studium porównawcze na podstawie badań uczniów I Liceum Ogólnokształcącego Collegium Gostomanium w Sandomierzu i I Liceum Ogólnokształcącego im. Stefana Żeromskiego w Chobrzanach. Stalowa Wola: Katolicki Uniwersytet Lubelski Jana Pawła II.

Sowińska, H. (2006). Autorytety i wzorce współczesnej młodzieży. Zeszyty Naukowe Wyższej Szkoły Pedagogiki i Administracji w Poznaniu, 2, s. 21-27.

Świda-Ziemba, H. (2005). Młodzi w nowym świecie. Kraków: Wydawnictwo Literackie.

Wagner, I. (2005). Stałość czy zmienność autorytetów: pedagogiczno-społeczne studium funkcjonowania autorytetu w zmieniającym się społeczeństwie. Kraków: Oficyna Wydawnicza IMPULS.

Witkowski, L. (2011). Historie autorytetu wobec kultury i edukacji. Kraków: Oficyna Wydawnicza IMPULS.

Witkowski, L. (2009). Wyzwania autorytetu w praktyce społecznej i kulturze symbolicznej: (przechadzki krytyczne w poszukiwaniu dyskursu dla teorii). Kraków: Oficyna Wydawnicza IMPULS.

Wysocka, E. (2009). Młodzież a autorytety: Analiza teoretyczna i empiryczne egzemplifikacje. Funkcjonowanie autorytetów w życiu codziennym młodzieży szkół średnich a religijność. W: J. Sieradzan (red.), Mit autorytetu, autorytet mitu (s. 285-322). Białystok: UwB. 